\title{
DISPOSITIONAL FACTORS INFLUENCING VULNERABILITY TO PERCEIVED WORKPLACE VIOLENCE AMONG NURSES IN ONDO AND OSUN STATES, NIGERIA
}

\author{
OLUFUNMILAYO ADEDAYO $^{1}$, AJIBOLA ISHOLA $^{2}$ \\ ${ }^{1} \mathrm{PhD}$, Senior Lecturer in the Department of General Studies. Adeyemi College of Education, \\ Ondo (Nigeria) \\ ${ }^{2}$ Clinical Psychologist and Graduate student in the Department of Psychology, University of \\ Ibadan (Nigeria) \\ ORCID ID: https://orcid.org/0000-0002-8208-9517
}

UDC: 159.9

\section{SUMMARY}

Perceived workplace violence against nurses has become a major concern to scholars, occupational safety and health administrators. However, dispositional factors in nurses' perception of workplace violence in Nigeria have not been sufficiently explored. This study therefore, examined dispositional factors predicting workplace violence among nurses in Ondo and Osun State, Nigeria.

The study adopted the cross-sectional study across the study setting; four hundred and fifteen (415) nurses from 14 health centres consisting of primary, secondary and tertiary health centres were selected using multi -stage sampling technique. A structured questionnaire which focused on socio-demographic characteristics, perceived workplace violence ( $\alpha=0.91)$, trait anger (TA) $(\alpha=0.67)$, negative affectivity (NA) $(\alpha=0.96)$, self control (SC) ( $\alpha=0.83)$ was used. Data was analysed using multiple regression, one-way ANOVA, and independent t-test at $p<.05$ level of significance.

The results reveal that the respondents' average age was $39.89 \pm 12.12$ years. Females (83.1\%) constituted the larger percentage of the respondents. $64.8 \%$ were registered nurses (RN), $28.4 \%$ had Nursing degree, $3.4 \%$ had Masters' degree and $2.4 \%$ had other qualifications. The nurse worked in the floor shifts $(31.6 \%)$, critical care $(22.9 \%)$, intensive care $(18.3 \%)$ and the operating room $(12 \%)$ units. Nurses' trait anger $(\beta$ $=.15)$, negative affectivity $(\beta=.13)$ organisational attribution style $(\beta=.15)$ were significantly associated

Address for correspondence, e-mail : editpsychas@gmail.com

Copyright: @ Olufunmilayo Adedayo, Ajibola Ishola

This is an Open Access journal, all articles are distributed under the terms of the Creative Commons AttributionNonCommercial-ShareAlike 4.0 International (CC BY-NC-SA 4.0) License (http://creativecommons.org/licenses/by-nc$\mathrm{sa} / 4.0 /$ ), allowing third parties to copy and redistribute the material in any medium or format and to remix, transform, and build upon the material, provided the original work is properly cited and states its license. 
with frequent experience of perceived workplace violence.

In conclusion, nursing staff dispositional traits and attribution styles makes them vulnerable to workplace violence.

Keywords: workplace violence, nurses, perception, dispositional traits.

Workplace violence has become one of greatest health and safety concerns in the $21 \mathrm{st}$ century (Escribano, Beneit \& Luis Garcia, 2019; Emmerik Euwema, Bukker \& Bukler 2007). The global picture shows that violence is widespread in the health sector. Nursing profession is one of occupations the most exposed to high incidence of workplace violence. International studies reports that the violence rate among nurses varied from $10 \%$ to $50 \%$ and even up to $87 \%$ in some places (Adedayo \& Ishola, 2018). In Nigeria the incidence of workplace violence against nurses is on the increase (Adedayo \& Ishola, 2018). Nurses are the people who are charged with providing care to the citizens of the state. They are the essential personnel needed for maintaining a healthy nation. They ensure speedy recovery from sickness to continue living healthy life. Unfortunatedly, in most of the hospitals, nurses are exposed to series of verbal abuses, bullying, mobbing, sexual harassment from patients, patients' relatives, supervisors and co-workers (Adedayo $\&$ Ishola, 2018). The incidence of workplace violence is high in public nursing sector and patients/ patient relations/ co-workers are the major perpetrators of workplace violence, while the existing workplace violence policy does not decrease the levels of workplace violence (Adedayo \& Ishola, 2018).
Nurses' presence in situation such as accidents, patient's death, long queue to see a doctor, or transfer of patients to a ward or another exposes them to harsh behaviour from patients or their companion and other hospital staff. Some issues such as long working hours, having to continually control conditions, hospital overcrowding, repeated request by patients and their companions for special privileges, lack of personnel, are situations which can also expose nurses to harsh and insulting situations in hospitals and can sometimes can cause illogical and tense reactions among nurses, other staff, patients and their companies. Some literature notes numerous dispositional factors that may account for individual differences that are associated with the incidence of workplace violence. These factors include trait anger, negative affectivity, impulsivity, selfcontrol, hostile attribution bias, Type A behaviour, agreeableness (Barling, Dupré, \& Kelloway, 2009; Douglas \& Martinko, 2001). While other studies note that dispositional factors play a role in workplace violence, but this process is not well articulated (Kuin, Masthoff, Munafò, \& PentonVoak, 2017).). In a recent thesis (Adedayo, 2018), the role of anger trait, negative affectivity, self-control, organizational attribution is discussed. 
"Trait anger" refers to the enduring personality trait of anger proneness. Persons with "trait anger" are always ready to detect violence threats and dangers in the world around them, such that they have a stable dispositional characteristic of anger (Pease, 2016). Numerous people are associated to express anger more as often than others (Schultz, Grodack, \& Izard, 2010). Montoya et al, (2012) identified that in order to maintain social dominance, individuals with high anger trait attempt to detect anger and threat it quickly, easily perceive this threat as challenging and allocate more processing resources to these faces. These interpretational biases may simply reflect tendencies for individuals with anger trait to expect that others will have feelings and motivations similar to theirs. Based on these, it is expected that nurses with high anger trait are more likely to perceived violence or threat it whether real or intended. They may tend to act provocatively based on their perceptions (Montoya et al, 2012).

Negative affectivity is defined as the extent to which individuals experience distressing emotions such as hostility, fear and anxiety (Hershcovis et. al., 2007). Individual who are high in negative affectivity are more sensitive and more reactive to negative events (Hershcovis et. al., 2007). Research evidences that negative affectivity correlates positively with detection of threat or violence behaviour. Bauer and Spector (2015); Meier and Semmer (2013) have shown that negative affectivity relates to both violence behaviour towards organization and detection of threat toward persons. Penney and Spector (2002) asserted that when confronted with stressful conditions, high negative affectivity individuals may ascribe more malicious motives to the actor leading to increased emotional arousal which may lead to violent behaviour. Individuals low in negative affectivity, on the other hand may give the actor the benefit of doubt and attribute the behaviour to more benign causes, enabling them to proceed without feeling the need to respond or retaliate with violence. Research findings have indicated that persons under stressful condition who report high levels of negative affectivity are more likely to report violent behaviour (Fortunato, \& Harsh, 2006; Rydstedt, et al., 2013). This study also hypothesised that negativity affectivity will be associated with incidence of perceived workplace violence.

Tangney, et al. (2004) indicated that self-control is related to the individual's ability to manage his or her frustrations. They argue that individuals with low self-control detect violent behaviours more often than individuals with high self-control because low-self-control individuals lack strong inhibitions, which is characteristic of high-self-control individuals. Tangney et al. (2004) propose that individuals with better selfcontrol are likely to remain calm during provocative situations. In contrast, people with low-selfcontrol can be described as those who have a "stable tendency to react offensively to minimal provocations" (Adedayo, 2014). This study as- 
sumes that nursing staff with reporting low selfcontrol will report on violence provoking situations more often than those with high self-control. This will also be tested in the present study.

Attribution Style (AS) is an individual-differences variable that refers to the habitual ways in which people explain their positive and negative life experiences (Kwan \& Wong, 2014). Specifically, studies suggest that the likelihood of individuals responding violently to negative situations depends partly on their judgments of causality (i.e. to what they attribute the cause of the negative situations). Moreover, within the workplace context, Aquino, Douglas and Martinko (2004) affirm that when individuals exhibit tendencies to attribute negative workplace outcomes to other persons or the employment organization (i.e. external attributions) and believe that these outcomes were controllable, intentional, and stable and that there were no mitigating circumstances, anger and subsequent violence are more likely to be demonstrated than if individuals exhibit tendencies to attribute the causes to factors that are internal, uncontrollable, unintentional, or unstable. This study theorises that nursing staff, who frequently make subjective negative attribution of co-workers and patients, will likely report more exposure to workplace violence. These assumptions were empirically tested in this study.

\section{Objective}

The study focus is to examine the possible link between risk/vulnerability factors and an increased risk of workplace violence, because of a dearth of empirical research in this area in the Nigerian health care system. The study investigates dispositional factors predicting perceived workplace violence against nurses in Ondo and Osun States of Nigeria. Specifically the study examined:

1. The relationship between nurses' anger trait, negative affectivity, self-control, organizational attribution and perceived workplace violence.

2. The role of trait anger, negative affectivity, self-control and organizational attribution style as predictors of perceived workplace violence.

\section{Method}

\section{Design:}

The study was a cross-sectional survey study conducted to the identified dispositional factors associated with workplace violence in some selected health facilities in Osun and Ondo states, Nigeria. Ethical approval for the study was obtained from the UI/UCH Ethical Review Committee with approval number UI/EC/14/230.

\section{Participants}

The study involved 415 participants across 14 public hospitals based in Ondo and Osun states, Nigeria from an estimated population of 1,481 employees. Using the sample size determination technique, 415 nurses were estimated using Kish (1965) sampling formula. The multi-stage sampling technique was used in se- 
lecting the sample from the population of nurses for the study. Stratified random sampling was used to select 415 nurses from primary, secondary and tertiary health care facilities from Osun and Ondo states.

\section{Instrument}

The main instrument was a structured questionnaire contains items on socio demographic variables (age, sex, marital status, educational qualification, work setting, work experience) and standardized scales. Anger trait was measured with 10-items State Trait Anger Scale developed by Speilberger, (1996) $(\alpha=0.70)$. Nurses' negative affectivity disposition was measured with Negative Affect Scale by Watson and Clark, (1984) ( $\alpha=0.82)$. Self-control was assessed in the study with the 13-items Self Control Scale (Tangney, Baumeister\& Boone, 2004) ( $\alpha=$ 0.84). Attribution Style was captured with 35items Organisational Attribution Scale Style (Kent \&Martinko, 1995) $(\underline{\alpha=0.70)} .5$-point response format was used for measurements. Perceived workplace violence was captured with 11items Nurses workplace violence behaviour scale by Adedayo, (2018) with 5-point response format ( $1=$ never, $2=$ rarely, $3=$ sometimes, $4=$ very often, 5 = always). The reliability alpha was 0.89 , the higher score on the scale means the higher experience of workplace violence.

\section{Procedure}

Before choosing the research sample, the researchers selected the health care facilities through multi-level selection sampling procedure. 14 health care facilities were selected from which the nurses were randomly sampled. The researchers obtained the endorsements from the officers in-charge at each of the healthcare facility before embarking on the investigation in each facility. The chief medical officer in control appointed the Nursing manager to request the cooperation of the nurses for the study. The researchers also obtained consents from the respondents before giving the questionnaire to them. The survey was organised to the nurses at work. The copies of the questionnaire were gathered after completion. Well completed copies of the questionnaire were used in the data analysis.

\section{Method of Statistical Analysis}

The information was coded and examined utilizing SPSS v22.0. The statistical tool used incorporate descriptive and inferential statistics which incorporate Pearson Product Moment Correlation (PPMC), Multiple Regression and Analysis of Variance (ANOVA) at $p \leq 0.05$.

\section{Results}

\section{Demographics characteristics of the respond- ents}

The demographic distributions of the participants show that $83.1 \%$ were females. The larger percentage (81.9\%) were married. $64.8 \%$ were registered nurses (RN) (269(64.8\%), 28.4\% (118) were degree holder, 3.4\% had master's degrees and $10(2.4 \%)$ had other qualifications. The larger percentages work the floor shifts $(31.6 \%)$, 
$22.9 \%$ works at the critical care unit, $18.3 \%$ at the intensive care units and $12 \%$ at the operating rooms.

Objective1: Relationship between nurse anger trait, negative affectivity, self-control, organizational attribution, staffing adequacy, nurse physician and perceived workplace violence. This objective was analysed using Pearson correlation analysis and the result presented in Table 1.

Table 1 reveals that there is significant positive relationship between anger trait $(r=.20$, having organisational attribution bias reported more often workplace violence than nurses with low negative affectivity and those who had lesser organisational attribution bias. The result indicates that the more nurses express anger trait, negative affectivity and organisational attribution style, the more often they perceive workplace violence in the healthcare facilities. Dispositional factors (Trait anger, Negative affectivity and organisational attribution style) significantly, independently and jointly, related to nurses' perceived

Table 1: Zero-order Correlation Showing the Relationship Between Nurse Anger Trait, Negative Affectivity, Self-Control, Organizational Attribution, Staffing Adequacy, Nurse Physician and Perceived Workplace Violence

\begin{tabular}{lccccccc}
\hline Variables & $\bar{x}$ & $\mathrm{SD}$ & 1 & 2 & 3 & 4 & 5 \\
\hline 1. Perceived workplace violence & 28.00 & 8.97 & - & $.20^{* *}$ & $.18^{* *}$ & 0.04 & $.16^{* *}$ \\
2. Anger trait & 19.87 & 5.25 & & - & $.25^{* *}$ & $.18^{* *}$ & 0.09 \\
3. Negative affectivity & 12.83 & 4.93 & & & $-13^{*}$ & 0.04 \\
4. Self-control & 19.64 & 6.18 & & & & - & $.11^{*}$ \\
5. Organisational attribution style & & & & & & & \\
\end{tabular}

**Correlation is significant at the 0.01 level (2-tailed).

*Correlation is significant at the $\mathbf{0 . 0 5}$ level (2-tailed).

$\mathrm{p}<.01)$, negative affectivity $(\mathrm{r}=.18, \mathrm{p}<.01)$, organisational attribution style $(\mathrm{r}=.16, p<.01)$, and perceived workplace violence. Nurses with high scores on anger trait frequently experience workplace violence while those with low anger trait reported lower incident workplace violence. Nurses with high negative affectivity and those workplace violence in the health care centres.

Objective 2: Trait anger, negative affectivity, self-control and organizational attribution style as predictors of perceived workplace violence. This objective was analysed using multiple regression analysis and the result are presented in Table 2. 
The result shows that the respondents' tor of perceived workplace violence $(\beta=.15, \mathrm{t}=$ anger, negative affectivity, self-control and or- $3.05 ; p<.01)$. 1-point increase in workplace vio-

Table 2: Summary of Multiple Regression Analysis showing the Influence of Trait Anger, Negative affectivity, Self-control and Organizational Attribution Style on Perceived Workplace Violence

\begin{tabular}{|l|l|l|l|l|l|l|l|}
\hline Predictors & \multicolumn{1}{|c|}{$\beta$} & $\mathbf{t}$ & $\mathbf{P}$ & $\boldsymbol{R}$ & $\boldsymbol{R}^{\mathbf{2}}$ & $\boldsymbol{F}$ & $\boldsymbol{P}$ \\
\hline Anger trait & \multicolumn{1}{|c|}{$\boldsymbol{\beta}$} & 3.040 & $<.01$ & & & & \\
\hline Negative affectivity & .133 & 2.700 & $<.01$ & & & & \\
\hline Self-control & -.021 & -.423 & $>.05$ & .28 & .08 & 8.38 & $<.01$ \\
\hline Organizational attribution style & .146 & 3.050 & $<.01$ & & & & \\
\hline
\end{tabular}

ganizational attribution style predict significantly jointly perceived workplace violence $\left(\mathrm{R}^{2}=0.11\right.$, $\mathrm{F}(4,409)=8.39, p<.01)$. This means that when combined, trait anger, negative affectivity, selfcontrol and organizational attribution style predict or account for $8 \%$ of the change observed in the total variation in the reported workplace violence among the nurses. The result reveals that trait anger $(\beta=.15, \mathrm{t}=3.04 ; p<.05)$ predicted workplace violence. For every 1 unit increase in workplace violence experienced by the nurse was due to .15 increase sensitivity through anger trait. It means that nurses with high anger traits are more likely to be victim of workplace violence than those with low anger trait. Also, negative affectivity as a predictor $(\beta=.13, \mathrm{t}=2.70 ; p<.05)$ means that 1-point increase in workplace violence experienced by the nurse was due to .13 increase negative mood state. So, nurses who frequently experienced negative emotions are more likely to be victim of workplace violence more than nurses experiencing positive emotional states. Organizational attribution style is also a significant predic- lence is associated with .15 standard deviation increase in subjective attribution errors. Frequently making biased organisational attributions are associated with frequent experience of workplace violence. However, self-control $(\beta=-.02, \mathrm{t}=-.42$; $p>.05)$ does not significantly predict perceived workplace violence. So, increase or decrease in workplace violence was not significantly associated with self-control or self -restraint when nurses are faced with provocations. These results demonstrates that frequent experience of negative emotional states, possessing anger trait and making subjective attribution errors makes nurses become more vulnerable and sensitive to workplace violence.

\section{Discussion}

The results demonstrate that frequent experience of negative emotional states, possessing anger trait and subjective attribution errors makes nurses more vulnerable and sensitive to workplace violence. Nurses with high anger traits are more likely to be victim of workplace violence than those with low anger trait. Tendency to be 
quick to anger often provoke retaliatory behaviour form the patients or colleagues. This finding supports findings of De Steno et, al, (2000) and Baumann (2012), believed that anger may make individuals to feel that they are more likely to encounter an anger-relevant stimuli compared to a neutral individual. It can therefore be deduced that Nigerian nurses with high anger trait detect workplace violence more often than nurses with low anger trait. However, if nurses have low trait anger, the influence of workplace violence for them would be reduced.

The findings also reveal that negative affectivity significantly predicts perceived workplace violence. This is in agreement with some previous studies (Wingrove \& Bond, 2005), which elucidated that high trait-anger individuals are more likely to respond violently to particular situations than the low-trait anger individuals. This is because high trait anger individuals are assumed to perceive a wider range of situations as anger provoking than the low trait-anger individuals (Takebe, Takahashi \& Sato 2016).This is in agreement with Penny and Spector (2005) who demonstrated that when individual are confronted with stressful conditions, high negatively affective individuals may acquire more malicious motives to an actor leading to increased emotional arousal which may lead to detection of violence or violent behaviours.

The results show that organisational attribution styles independently have a significant influence on perceived workplace violence. This aligns with the previous studies that a person's cognitive appraisals of negative outcomes may predict violence. Specifically, the literature suggests that the likelihood of individuals' violent responses to negative situations depends partly on their judgements of causality (Gaynes, Brown \& Lux, 2016). In addition, the result of the studies on aggression in general, conducted by Dodge et. al. (2015) and Kuin et al. (2017), show that the individuals exhibit a hastened tendency to attribute hostile intent to other people's actions, even when such actions are ambiguous. Thus, on the basis of theory and research from the organisational and social psychology literature, it appears that hostile attribution style may be related to the incidence of workplace violence. This study confirmed that hostile organizational attribution style increased the incidence of perceived workplace violence.

Self-control does not independently predict perceived workplace violence. This result is contrary to the view of early studies which confirmed that self-control is a predictor of workplace violence. Literature on self-control (Barling et. al., 2009) demonstrates that inability of individuals to manage their emotions may be related to the incidence of workplace violence, whereas, according to Schulz, (2015), individuals who possess higher levels of self-control often remain calm at provocative situations. Individuals with lower self-control are likely to respond violently at provocative situations. The findings as reflected shows that self-control have a threshold espe- 
cially when managing a crowd. That is the concept of trait anger, negative affectivity, and organisational attribution styles appear to be related in the theory and the research. Although we are unaware of any research that directly link all these variables. However, there is a reasonable probability that these four variables interact to influence perceived workplace violence.

\section{Conclusion, Implication and Recommenda- tions}

This study tested a conceptual model in which dispositional characteristics are expected to be vulnerability factors for workplace violence among nursing staff. Dispositional factors were demonstrated to explain a part of the victimization process. Nurses who frequently experienced negative emotional states, possessed anger trait and makes subjective attribution errors are more likely to be assaulted or abused at their place of work. The result of the study on the proposed empirical model is really important for practical use in various ways. Screening for vulnerable personal characteristics amid the staff recruitment procedures of nursing staff reduces the hazard for encountering workplace violence. The research discoveries are essential in the advancement of preparing programs in the avoidance of workplace violence and for sufficient observing and supervision of staff with personal traits powerless against workplace violence. A specially designed activity that support the vocation and stop revictimisation for existing staff should be provid- ed. Further elaboration on the diverse segments of the identity attributes discussed in this article and their impact on hospital environment are profoundly important for staffing choices. It is vital that future investigations will be centred on such communications between nurses, health workers and patients that can lead to violence situation. The study is a cross-sectional study which is liable to social response bias and weak for the establishment of causal-effect relationship. Future studies should consider longitudinal and observational research approaches.

\section{References (Transliteration):}

Adedayo, F., (2014) Personality factors as predictors of bullying among secondary school students in south western Nigeria. International Journal of Technical Research and Applications, 2(7): 1-4. www.ijtra.com.

Adedayo, O. \& Ishola, A., (2018) Organisational factors predicting perceived workplace violence among nurses in Ondo and Osun States, Nigeria. African Journal for the Psychological Study of Social Issues.21, 48-61.

Adedayo, O. (2018) Individual and organizational factors as predictors of nurses' perceived workplace violence in Ondo and Osun States, Nigeria. An unpublished Ph.D thesis submitted to the Department of Psychology, Faculty of the Social Science, University of Ibadan.

Barling, J., Dupré, K. E., \& Kelloway, E. K. (2009). Predicting Workplace Aggression and Violence. Annual Review of Psychology, 60(1), 671-692. doi:10.1146/annurev.psych.60.110707.1 
Bauer, A. J. \& Spector, P.E. (2015) Discrete Negative Emotions and Counterproductive Work Behavior, Human Performance, 28:4, 307-331, DOI: 10.1080/08959285.2015.1021040

Baumann, N. (2012). Autotelic personality. In S. Engeser (Hrsg.) Advances in flow research (9. Kapitel, S. 165-186)). Heidelberg, Germany: Springer.

Dodge, K. A., Malone, P. S., Lansford, J. E., Sorbring, E., Skinner, A. T., Tapanya, S., ... Pastorelli, C. (2015). Hostile attributional bias and aggressive behavior in global context. Proceedings of the National Academy of Sciences of the United States of America, 112(30), 9310-9315. doi:10.1073/ pnas. 1418572112.

Douglas, S. C., \& Martinko, M. J. (2001). Exploring the role of individual differences in the prediction of workplace aggression. Journal of Applied Psychology, 86,547-559.

Emmerik, H.V., Euwema, M. \& Baker (2007). Group and organization management. Sage Publication.32, (2): 52-60.

Escribano, R. B., Beneit, J., \& Luis Garcia, J. (2019). Violence in the workplace: some critical issues looking at the health sector. Heliyon, 5(3), e01283. doi:10.1016/j.heliyon.2019.e01283

Fortunato, V.J., \& Harsh, J. (2006). Stress and sleep quality: The moderating role of negative affectivity. Personality and Individual Differences, 41, 825836.

Fox, S., Spector, P.E. \& Miles, D. (2001). Counterproductive Work Behaviour CWB in response to stressors and organizational justice: Some mediator and moderator tests for autonomy and emotions. Journal of Vocational Behaviour, 59:291-301.

Gaynes, B.N., Brown, C. \& Lux, L.J. (2016) 'Strategies To De-escalate Aggressive Behavior in Psychiatric Patients [Internet].', Agency for Healthcare Re- search and Quality (US), viewed 4 May 2019, https:/www.ncbi.nlm.nih.gov/books/ NBK379388/

Hegney, D., Eley, R., Plank, A., Buikstra, E. \& Parker, V. (2006). Workplace violence in Queensland, Australia: The results of a comparative study. International Journal of Nursing Practice, 12, 220-231.

Hegney, D., Tuckett, A., Parker, D. \& Eley, R.M. (2010). Workplace violence: Difference in perceptions of nursing work between those exposed and those not exposed: A cross sector analysis. International Journal of Nursing Practice, 16(2): 188-202.

Hershcovis, M.S., Turner, N., Barling, J., Arnold, K.A., Dupré, K.E., Inness, M., LeBlanc, M.M., Sivanathan, N. (2007). Predicting workplace aggression: A meta-analysis. Journal of Applied Psychology, 92, 228-238.

Kent, R. \& Martinko, M.J. (1995). The development and evaluation of a scale to measure organizational attribution style. In M. Martinko (Ed.), Attribution theory: An organizational perspective. Delray Beach, FL: St. Lucie Press. p53-75.

Kish, L.(1965). Survey Sampling. New York: John Wiley and Sons, Inc.

Kuin, N. C., Masthoff, E., Munafò, M. R., \& Penton-Voak, I. S. (2017). Perceiving the evil eye: Investigating hostile interpretation of ambiguous facial emotional expression in violent and non-violent offenders. PloS one, 12(11), e0187080. doi:10.1371/ journal.pone. 0187080

Kwan, S.-O., \& Wong, F.-K. D. (2014). The relationship between attributional style and destructive responses to job dissatisfaction: an exploratory study of internal migrant workers in China. Health Psychology and Behavioral Medicine, 2(1), 686-695. http://doi.org/10.1080/21642850.2014.919864.

Martinko, M.J. \& Zellars. K.L. (1998). Toward a theory of 
workplace violence: A cognitive appraisal perspective. In R.W. Griffin, A, O’Leary-Kelly, \& J.M. Collins (Eds.), Dysfunctional behaviour in organsations: Violent and deviant behaviour (pp.1 -42). Stamford, CT: JAI Press.

Meier, L. L. \& Semmer, N. K. (2013). Lack of reciprocity, narcissism, anger, and instigated workplace incivility: A moderated mediation model. European Journal of Work and Organizational Psychology, 22, 461-475. doi:10.1080/1359432X.2012.65460.

Montoya, E. R., Terburg, D., Bos, P. A., \& van Honk, J. (2012). Testosterone, cortisol, and serotonin as key regulators of social aggression: A review and theoretical perspective. Motivation and Emotion, 36 (1), 65-73. http://doi.org/10.1007/s11031-0119264-3.

Moss, S.E. \& Martinko, M.J. (1998). The effects of performance attributions and outcome dependence on leader feedback behaviour following poor subordinates performance. Journal of Organisation behaviour, 19,259-274.

O’Leary-Kelly, A.M., Griffin, R.W.\& Glew, D.J. (1996). Organisation-motivated aggression: A research framework. Academic Management Review, 21:225-253.

Pease, C. (2016) Examining the Role of Individual Differences within the Experience and Expression of Anger. PhD thesis, University of York.

Penney, L.M. \& Spector, P. (2005). Job Stress, Incivility, and Counterproductive Work Behavior (CWB): The Moderating Role of Negative Affectivity. Journal of Organizational Behavior, 26(7), 777 796. Retrieved from http://www.jstor.org/ stable/4093955.

Penny, L.M. \& P.E. Spector, (2002). Narcissism and counterproductive work behaviour CWB: Do bigger egos mean bigger problems? International Journal of Selection and. Assessment, 10:126-134.

Rydstedt, L.; Johnsen, S. Å. Kjøs; Lundh, M.. \& Devereux, J.(2013). (2013) The Conceptual Roles of Negative Positive Affectivity in the Stressor-Strain Relationship, Europe's Journal of Psychology, 2013, Vol. 9(1), 93-103, doi:10.5964/ejop.v9i1.537.

Schultz, D., Grodack, A. \& Izard, C.E. (2010). State and trait anger, fear and social information processing. In Potegal, M., Stemmler, G \& Speilberger, C. (Eds). International Handbook of Anger, (pp. 311328). New York: Springer.

Schulz, S. (2015). “Don”t Blow Your Cool': Provocation, Violent Coping, and the Conditioning Effects of Self-Control. Journal of Quantitative Criminology, 32(4), 561-587. doi:10.1007/s10940-015-9267-4

Speilberger, C.D. (1996). State-trait anger expression inventory, research edition: professional manual. Odessa, FL: Psychological Assessment Resources.

Takebe, M., Takahashi, F., \& Sato, H. (2016). Anger rumination as a risk factor for trait anger and angerin: A longitudinal study. Personality and Individual Differences, 101, 451-455. doi:10.1016/ j.paid.2016.06.038.

Tangney, J. P., Baumeister, R. F., \& Boone, A. L. (2004). High self-control predicts good adjustment, less pathology, better grades and interpersonal success. Journal of Personality, 72, 271-324. http:// dx.doi.org/10.1111/j.0022-3506.2004.00263.x.

Watson, D. \& Clark., L.A. (1984). Negative affectivity: The disposition to experience aversive emotion states. Psychological Bulletin, 96, 465-90

Wingrove, J. \& Bond, A.J. (2005). Correlation between trait hostility and faster reading times for sentences describing angry reactions to ambiguous situations. Cognition \& Emotion, 19, 463-472. 


\section{Олуфунмілао Адетау (Olufunmilayo Adedayo)}

Доктор наук, старший викладач кафедри загальних досліджень, Адейми освітній коледж, м. Ондо (Нігерія)

\section{Ажсібола Ісхола (Ajibola Ishola)}

Клінічний психолог $і$ аспірант кафедри психології Ібаданського університету, м. Ібадан (Нігерія)

\section{ДИСПОЗИЦІЙНІ ФАКТОРИ ВРАЗЛИВО- СТІ, ЯКА СПРИЧИНЯЄ НАСИЛЛЯ НА РОБОЧОМУ МІСЦІ ЩОДО МЕДИЧНИХ СЕСТЕР В ШТАТАХ ОНДО І ОСУН, НIГЕРІЯ}

\section{Анотація.}

Розуміння насильства на робочому місці проти медсестр стало серйозною проблемою для науковців, адміністраторів охорони праці та здоров’я. Тим не менш, диспозиційні фактори, що призводять до насильством на робочому місці щодо медичних сестер в Нігерії недостатньо вивчені. Таким чином, у цьому дослідженні розглянуті диспозиційні фактори, які призводять до насильства на робочому місці серед медсестр у штаті Ондо і Осун, Нігерія.

У дослідженні було проведено перехресне дослідження щодо чотириста п'ятнадцяти (415) медсестр 314 медичних центрів, що складаються 3 первинних, вторинних та третинних медичних центрів, які були відібрані 3 використанням багатоступеневої методики відбору проб. У дослідженні було використано структурований опитувальник, який зосереджувався на соціально-демографічних характеристиках, сприйнятті насильства на робочому місці $(\alpha=0,91)$, гніві ознак (ТА) $(\alpha=$
$0,67)$, негативній афективності (NA) $(\alpha=0,96)$, самоконтролі (SC) $(\alpha=0,83)$. Дані аналізували за допомогою множинної регресії, односторонньої ANOVA i незалежного t-тесту на $p$ $<0,05$ рівня значущості.

Результати показують, що середній вік респондентів становив $39,89 \pm 12,12$ років. Жінки $(83,1 \%)$ становили більший відсоток респондентів. 64,8\% були зареєстрованими медсестрами $(\mathrm{RN}), 28,4 \%$ мали ступінь медсестринства, 3,4\% мали ступінь магістра та 2,4\% мали інші кваліфікації. Медсестра працювала в зміщеннях на підлозі $(31,6 \%)$, критичній (22,9\%), реанімаційній $(18,3 \%)$ та операційній $(12 \%)$. Стани гніву медсестр $(\beta=0,15)$, негативна афективність $(\beta=.13)$ стилю організаційної атрибуції ( $\beta=.15)$ суттєво асоціювалися 3 частим досвідом сприйняття насильства на робочому місці.

Нарешті, диспозиційні стани та характеристики сестринського персоналу роблять їх вразливими до насильства на робочому місці.

Ключові слова: насильство на робочому місці, медсестри, сприйняття, диспозиційні стани. 


\section{Олуфунмилайо Адедайо}

Доктор наук, старший преподавател кафедры общчх исследований, Образовательный колледж Адейми, г. Ондо (Нигерия)

\section{Аджибола Ииола}

Клинический психолог и аспирант факультета психологии Ибаданского университета, г. Ибадан (Нигерия)

\section{ДИСПОЗИЦИОННЫЕ ФАКТОРЫ УЯЗ- ВИМОСТИ, КОТОРАЯ ВЕДЕТ К НАСИ- ЛИЮ НА РАБОЧЕМ МЕСТЕ В ОТНОШЕ- НИИ МЕДСЕСТЕР В ШТАТАХ ОНДО И ОСУН, НИГЕРИЯ}

\section{АННОТАЦИЯ}

Понимание насилия на рабочем месте против медсестер стало серьезной проблемой для ученых, администраторов охраны труда и здоровья. Тем не менее, диспозиционные факторы, приводящие к насилием на рабочем месте по медицинских сестер в Нигерии недостаточно изучены. Таким образом, в этом исследовании рассмотрены диспозиционные факторы, которые приводят к насилию на рабочем месте среди медсестер в штате Ондо и Осун, Нигерия.

В исследовании было проведено перекрестное исследование по четыреста пятнадцать (415) медсестер с 14 медицинских центров, состоящих из первичных, вторичных и третичных медицинских центров, которые были отобраны с использованием многоступенчатой методики отбора проб. В исследовании были использованы структурированный опросник, который сосредоточен на социально-демографических характеристиках, восприятии насилия на рабочем месте $(\alpha=0,91)$, гневе признаков (ТА) $(\alpha=0,67)$, отрицательной аффективности (NA) $(\alpha=0,96)$, самоконтроле (SC) $(\alpha=0,83)$. Данные анализировали с помощью множественной регрессии, односторонней ANOVA и независимого t-теста на $\mathrm{p}<0,05$ уровня значимости.

Результаты показывают, что средний возраст респондентов составил $39,89 \pm 12,12$ лет. Женщины $(83,1 \%)$ составляли больший процент респондентов. 64,8\% были зарегистрированы медсестрами (RN), 28,4\% имели степень медсестринства, 3,4\% имели степень магистра и 2,4\% имели другие квалификации. Медсестра работала в смещениях на полу $(31,6 \%)$, критической $(22,9 \%)$, реанимационной $(18,3 \%)$ и операционной (12\%). Состояния гнева медсестер $(\beta=0,15)$, негативная аффективность $(\beta=.13)$ стиля организационной атрибуции $(\beta=.15)$ существенно ассоциировались с частым опытом восприятия насилия на рабочем месте.

Наконец, диспозиционные состояния и характеристики сестринского персонала делают их уязвимыми к насилию на рабочем месте.

Ключевые слова: насилие на рабочем месте, медсестры, восприятие, диспозиционные состояния.

\section{Дата отримання статті: 07.07.2019 Дата рекомендації до друку: 15.07.2019 Дата оприлюднення: 25.07.2019}

